\begin{tabular}{|l|l|l||}
\hline \multicolumn{2}{|c|}{ PublisherInfo } \\
\hline \hline PublisherName & $:$ & BioMed Central \\
\hline \hline PublisherLocation & $:$ & London \\
\hline \hline PublisherImprintName & $:$ & BioMed Central \\
\hline \hline
\end{tabular}

\title{
Endocrine response: Is CGAthe key?
}

\begin{tabular}{||l|l|l||}
\hline \multicolumn{2}{|c|}{ ArticleInfo } \\
\hline \hline ArticleID & $:$ & 3769 \\
\hline \hline ArticleDOI & $:$ & $10.1186 /$ bcr-2001-68452 \\
\hline \hline ArticleCitationID & $:$ & 68452 \\
\hline \hline ArticleSequenceNumber & $:$ & 41 \\
\hline \hline ArticleCategory & $:$ & Paper Report \\
\hline \hline ArticleFirstPage & $:$ & 1 \\
\hline \hline ArticleLastPage & $:$ & 3 \\
\hline \hline & & RegistrationDate $\quad: \quad 2001-8-20$ \\
ArticleHistory & $:$ & Received \\
& Accepted $\quad$ 2001-4-30 \\
\hline \hline ArticleCopyright & $:$ & Biomed Central Ltd2001-8-20 \\
\hline \hline ArticleGrants & $:$ & \\
\hline \hline
\end{tabular}




\begin{tabular}{|l|l|l|l|}
\hline ArticleContext & $:$ & 1305833 \\
\hline
\end{tabular}

Valerie Speirs, ${ }^{\text {Affl }}$

Aff1 Molecular Medicine Unit, University of Leeds, UK

\section{Keywords}

\section{Context}

Oestrogen receptor (ER) is an established prognostic marker in breast cancer and expressed in about two thirds of all patients. The presence of ER is used routinely to predict response to adjuvant endocrine therapy. However, not all patients with ER-positive tumours respond, so there is a need to identify alternative markers of endocrine responsiveness. In this study, the authors evaluated the role of the $C G A$ gene (coding for the a subunit of glycoprotein) as a novel ER-responsive gene in a cohort of human breast tumours.

\section{Significant findings}

Overexpression of $C G A$ was observed in 44 of the 131 breast tumours tested. Significant associations were noted between $C G A$ overexpression and features indicating a low level of biological aggressiveness, including histological grades I and II, ER a and progesterone receptor. Overexpression of $C G A$ was not observed in ER-negative tumours, indicating its association with ER responsiveness, and immunohistochemical analysis showed $C G A$ was expressed exclusively in ER-positive tumour cells.

\section{Comments}

The $C G A$ gene has the potential to offer a more refined approach for the selection of patients for endocrine therapy. Future studies should focus on the expression of $C G A$ in in tumours sensitive or resistant to tamoxifen to determine if it is associated with survival advantage. On a technical note, high throughput screening of $C G A$ in a clinical setting would require further validation of the 
immunohistochemical technique, as TaqManR real-time PCR requires specialised and expensive equipment which may not be available to many pathology labs. Together with established markers of endocrine response, $C G A$ is an attractive new candidate which could help decide which patients might benefit from adjuvant endocrine therapy.

\section{Methods}

TaqManR real-time PCR, immunohistochemistry

\section{Additional information}

\section{References}

1. Bieche I, Parfait B, Le Doussal V, Olivi M, Rio M-C, Lidereau R, Vidaud M: Identification of $C G A$ as a novel estrogen receptor-responsive gene in breast cancer: An outstanding candidate marker to predict the response to endocrine therapy. Cancer Res . 2001, 61: 1652-1658. 